\title{
Resiko Transaksi Bisnis Syariah Baitul Maal Wat Tamwil Studi Kasus Produk Pembiayaan
}

\author{
Abdul Majid Toyyibi ${ }^{1 *}$, Imam Mawardi ${ }^{2}$ \\ ${ }^{1}$ Program Studi Perbankan Syariah, Fakultas Ekonomi dan Bisnis Islam, Sekolah \\ Tinggi Agama Islam Al - Fithrah Surabaya, ${ }^{2}$ Program Studi Ekonomi Syariah, \\ Universitas Sunan Giri Surabaya \\ Jln. Kedinding Lor No. 30 Surabaya, 60129, Indonesia
}

\begin{abstract}
In BMT, risk is identical with financing and risk is like an enemy that cannot be abandoned, must be fought and watched out for. Fighting and being wary of is meant so that there is an analysis process in accordance with applicable regulations carried out by certain parties such as BMT for policy purposes in determining the results of the analysis of financing. Then from here used the type and approach is qualitative by looking at case studies or events in the field until from the results of interviews and documentation, data analysis is carried out so that the data can be accounted for the validity of the data. From this research, it was found that BMT has tips to avoid high risk, at least there are preventive actions as a reference for generating a financing that indicates a risk.
\end{abstract}

Keyword: risk, sharia business, bmt, financing

Paper type: Research paper

*Corresponding author: abdulmajidtoyyibi93@ gmail.com

Received: 18 Januari2020, ; Accepted: 17 Juni 2021; Published: 30 Juni 2021

Cite this document: Toyyibi, A., M. Mawardi, I.,(2021).Resiko Transaksi Bisnis Syariah Baitul Maal Wat Tamwil Studi Kasus Produk Pembiayaan.BISEI: Jurnal Bisnis dan Ekonomi Islam, 6(1), 50-62

Copyright $@$ 2021, BISEI: JurnalBisnis dan Ekonomi Islam http://ejournal.unhasy.ac.id/index.php/bisei 
Abstrak: Dalam BMT resiko identik dengan pembiayaan dan resiko adalah ibaratkan musuh yang tak bisa ditinggalkan, harus dilawan dan diwaspadai. Dilawan dan diwaspadai dimaksudkan agar ada sebuah proses analisa sesuai ketentuan berlaku yang dilakukan oleh pihak tertentu seperti BMT untuk kepentingan kebijakan dalam penentuan hasil analisa dari pembiayaan. Kemudian dari sini digunakan jenis dan pendekatannya adalah Kualtitatif dengan melihat studi kasus atau kejadian dilapangan hingga dari hasil wawancara dan dokumentasi, dilakukan analisis data agar data tersebut bisa dipertanggung jawabkan validitas datanya. Dari penelitian ini dihasilkan bahwa BMT memiliki kiat-kiat agar bisa terhindar dari tingginya resiko, setidaknya ada tindakan preventif sebagai acuan dari timbulkan sebuah pembiayaan yang terindikasi adanya resiko.

Kata Kunci: resiko, bisnis syariah, bmt dan pembiayaan

\section{Pendahuluan}

Saat ini Indonesia sudah mulai masuk pada tatanan kondisi new normal, artinya disini segala aktivitas atau kegiatan mulai perkantoran, lembaga pendidikan dan lain sebagainya bisa berjalan seperti semula dengan diterapkan protokol kesehatan. Dengan berlalunya masa pandemi akan bisa memberikan perhatian khusus pada berubahnya suatu kondisi baik di sektor sosial, budaya dan ekonomi. Dibalik itu juga resiko pasti ada dan akan menjadi ancaman bagi kita terutama di sektor ekonomi.

Dalam kehidupan sehari-hari kita sering mendengar kata "Resiko" dan sudah biasa dipakai dalam percakapan sehari-hari oleh kebanyakan orang. Resiko merupakan bagian dari kehidupan kerja individual maupun organisasi. Berbagai macam resiko, seperti resiko kebakaran, tertabrak kendaraan lain di jalan, resiko terkena banjir di musim hujan dan sebagainya, dapat menyebabkan kita menanggung kerugian jika resiko-resiko tersebut tidak kita antisipasi dari awal. Resiko dikaitkan dengan kemungkinan kejadian atau keadaan yang dapat mengancam pencapaian tujuan dan sasaran organisasi. Sebagaimana kita pahami dan sepakati bersama bahwa tujuan perusahaan adalah membangun dan memperluas keuntungan kompetitif organisasi.

Sehingga resiko ini bisa menjadi kehati-hatian dari pihak lembaga keuangan untuk selalu bekerja secara professional dalam melakukan analisis customer. Meskipun resiko itu pasti ada namun meminimalisir adalah hal yang penting, setidaknya tindakan preventif berupa implementasi pada proses proses pembiayaan sesuai dengan kaidah atau anjurannya seperti dilakukan penilaian 5C.

Adapun transaksi bisnis syariah adalah sebuah aktivitas manusia dimana dalam kegiatannya menghasilkan untung atau rugi baik dilakukan secara individu ataupun kelompok dengan berdasarkan pedoman Al-Qur'an dan Hadist sebagai pijakan dalam melakukan kegiatan ekonominya. Menurut Dewi Anita (2019) dalam jurnal penelitian nya menyebutkan bahwa aktivitas ekonomi yang dilakukan secara individu atau kelompok menggunakan akad akad yang 
mendasari setiap transaksi bisnis, dengan motivasi seseorang dalam melaksanakan transaksi bisnis dan mengetahui sejauh mana transaksi bisnis dilakukan berdasarkan syara' serta bagaimana pelaksanaan akad dalam lembaga keuangan Syariah termasuk perbankan Syariah.

Hal senada juga diutarakan oleh Septarina Budiwati (2017) bahwa dengan transaksi bisnis syariah semua kegiatan ekonomi bisa dilakukan dan islam melalui aturan syariah nya memberikan fasilitas berupa pedoman yakni adanya akad-akad yang bisa menjadi rujukan dalam melakukan kegiatan bisnis syariahnya sehingga bisa terhindar dari hal-hal yang tidak di inginkan seperti berbohong, penipuan, penggelapan dan lain sebagainya.

Sehingga bisa disimpulan bahwa bisnis syariah itu segala sesuatu yang berhubungan dengan jual beli yang berlandaskan hukum syariah yakni Al-Quran dan Hadist. Bisnis syariah itu sendiri berawal dari dua jenis kata yaitu bisnis dan syariah. Bisnis adalah segala sesuatu yang berhubungan erat dengan jual beli atau tijarah. Definisi syariah berarti sumber jalan yang lurus. Kemudian secara istilah syariah artinya perundang-undangan yang diturunkan oleh Allah SWT melalui Nabi Muhammad SAW untuk semua umat manusia baik yang menyangkut masalah ubudiyah, akhlak, food, drink, cloth maupun muamalah. Aktivitas bisnis syariah tidak hanya melakukan jual beli yang targetnya mendapatkan keuntungan. Namun dilain sisi bisnis ini lebih mengarah kepada hukum Islam yang sesuai dengan Al Quran dan Hadis. Sehingga bisnis ini dibatasi oleh sistem atau cara mendapatkan keuntungan dan mengembangkannya dengan konsep yang jelas (halal dan haram). Dilihat dari halal dijalankan namun bila haram maka ditinggalkan. Sehingga bukan tentang keuntungan saja namun juga mendapatkan keridhoan dari Allah SWT.

Irdhon Sahil (2019) Perkembangan BMT sejak mulai pertama kali diperkenalkan pada awal 2000-an sampai periode ini terus mengalami peningkatan dan bisa mencapai titik yang luar biasa. Sejauh ini pengawasan (controlling) dan pembinaan lembaga keuangan mikro syariah termasuk koperasi BMT yang berada pada dua kelembagaan atau badan hukum yaitu Otoritas Jasa Keuangan (OJK) dan Kementerian Koperasi. Adapun sebagian besar BMT atau lembaga Keuangan Mikro di Indonesia memilih untuk berbadan hukum koperasi.

Kemudian sebagian hanya beberapa saja yang memilih untuk dibawah OJK. Meskipun demikian, potensi dan peluang BMT belum banyak diketahui oleh masyarakat, sehingga penggunaannya hanya sebatas masyarakat menengah ke bawah dan belum merata. Selain itu, banyak orang yang tidak percaya (aneh) bahwa BMT bisa berkembang pesat menjadi perusahaan LKS non bank yang mampu menjamin kesejahteraan manajer atau karyawannya. Mengingat manfaat dan perannya yang sangat penting dalam pengembangan ekonomi umat, dan sudah saatnya pemerintah memberi perhatian yang lebih besar kepada BMT. Ungkap Fathur Rozi selaku pegawai BMT Al Fithrah.

Ahmad Rodoni (2008) Pengertian Baitul Maal wat Tamwil secara definitive adalah balai usaha mandiri terpadu yang isinya berintikan konsep Baitul Maal wat Tamwil yang kegiatannya adalah mengembangkan usahausaha produktif dan investasi dalam mengembangkan kualitas kegiatan 
ekonomi pengusaha makro dan kecil, antara lain mendorong kegiatan menabung dan pembiayaan kegiatan ekonominya.

BMT Al Fithrah merupakan lembaga keuangan yang baru saja berdiri, meskipun masih baru berdiri tentu memiliki resiko didalam lembaga tersebut, BMT Al Fithrah memiliki cara untuk mengatur resiko di dalam lembaganya mulai dari penerapan resiko diawal pembiayaan nasabah sampai dengan pensurveiian nasabah, pada kesempatan kali ini kelompok kami akan membahas tentang bagaimana BMT Al Fithrah mengatur, menghindar dan menerapkan prinsip kehati-hatian pemberian pembiayaan kepada nasabah.

Adapun Rumusan masalah pada penelitian ini adalah Bagaimana BMT mengatur resiko pembiayaan, strategi apa yang dilakukan untuk mrnghindari resiko tersebut, dan bagaimana BMT menerapkan prinsip kehati hatian.

\section{Metode Penelitian}

Dalam Penelitian ini menggunakan metode penelitian kualitatif yaitu dengan menggambarkan secara sistematis, secara akurat (bisa dipertanggungjawabkan), faktual mengenai fakta lapangan dan sifat yang ada pada obyek penelitian secara kualitatif. dimaksudkan dalam penelitian ini peneliti akan menggali dan mengungkap sebuah case study atau masalah yang terjadi di lapangan tentang resiko bisnis syariah BMT dari produk pembiayaan nya.

Adapun Jenis data nantinya berupa hasil wawancara dengan informan, jenis sumber data yang digunakan adalah primer, yakni di mana peneliti memperoleh data secara langsung dari sumber informasi (informan) melalui hasil observasi dilokasi penelitian, wawancara secara intens dan mendalam serta mendokumentasikan yang dilakukan oleh peneliti. Selanjutnya adalah melakukan teknis analisa data, dilakukan dengan cara mengumpulkan dan menginterpretasi data dengan melakukan perbandingan antara hasil dan teori yang ada serta memadukan hasil observasi, wawancara dan dokumentasi dan terakhir dilakukan keabsahan data.

\section{Hasil dan Pembahasan}

\section{Pengaturan Resiko Pembiayaan Di BMT Al Fithrah}

Aktivitas penyaluran dana di BMT Al Fithrah dalam bentuk pembiayaan, pastinya tidak akan terlepas dari resiko pembiayaan bermasalah (macet) yang sebabkan dari ketidakmampuan nasabah dalam membayar atau melunasi kreditnya (pembiayaan) kepada pihak BMT. BMT juga tidak terlepas dari pembiayaan bermasalah, adapun untuk menghindari dari hal tersebut maka pihak BMT membutuhkan suatu strategi dalam mengatur guna meminimalisir pembiayaan yang akan menimbulkan resiko tersebut. Ketika melihat tingkat loyalitas kemampuan pembayaran nasabah yang masih dibawah standar dan kurang maksimal pencapaiannya, tentu ini menjadi tantangan pihak bank bahwa harus selektif dan prinsip hati-hati untuk menyalurkan pembiayaannya kepada nasabah lain. Kemudian salah satu faktor penyebab dari nunggaknya pembayaran nasabah adalah faktor alam yang dominan seperti terjadi covid-19, gagal panen, angin kencang bagi nelayan, dan lain-lain. 
Faktor lain juga ada seperti kurangnya keseriusan dari nasabah untuk membayar cicilan pembiayaannya dan masih banyak lagi faktor lain bagi nasabah untuk menunggak pembayarannya. Sehingga mengatasi dari terjadinya tunggakan nasabah dalam pembayaran pembiayaannya, perlu dilakukan strategi dan win solution yang dilakukan oleh bank syariah untuk menyelamatkan pembiayaan bermasalah contohnya melakukan pembinaan kepada nasabah, pemberian surat peringatan pada nasabah 1-2x, mengatur penjadwalan kembali (rescheduling), persyaratan kembali (reconditioning), penataan kembali (restructuring), dan penyitaan jaminan sampai kepada write off. Ada juga upaya yang esensial secara syariah yang dilakukan oleh BMT Al Fithrah adalah dengan sistem kekeluargaan dengan musyawarah bila terjadi hal hal yang bermasalah dalam proses pembiayaannya, ini sangat berbeda dengan pembiayaan di lembaga konvensional yang menitikberatkan pada profit saja (penyitaan jaminan yang lebih diutamakan).

Menurut Adiwarman Karim (2006) Terdapat tiga jenis resiko yang bisa muncul dari lemahnya bank, yaitu sebagai berikut:

1. Analisis pembiayaan yang salah

Analisis pembiayaan yang salah, dalam konteks ini dimaksudkan, terjadi nya bukan karena perubahan kondisi nasabah yang tidak terduga, tetapi disebabkan memang sejak awal nasabah yang bersangkutan beresiko tinggi. Keputusan hasil pembiayaan bisa jadi adalah keputusan ini biasanya bersumber dari informasi yang tersedia. Untuk mengatasi hal ini, baik memerlukan staf yang terlatih dan berpengalaman dalam menyusun suatu pendekatan pembiayaan.

2. Creative accounting

Creative Accounting adalah istilah yang diterapkan untuk menggambarkan penggunaan kebijakan akuntansi perusahaan yang memberikan informasi keterangan menyesatkan tentang suatu laporan posisi keuangan 8 perusahaan calon nasabah. Dalam kasus seperti ini, manfaat dan keuntungan dapat dibuat agar bisa terlihat lebih besar, asset terlihat lebih bernilai, dan kewajiban-kewajiban dapat disembunyikan dari neraca keuangan.

3. Karakter nasabah.

Kadang-kadang nasabah dapat memperdaya bank dengan sengaja menciptakan pembiayaan macet, bank atau BMT perlu waspada terhadap kemungkinan ini dengan mencoba untuk membuat suatu keputusan yang akurat berdasarkan informasi obyektif tentang karakter nasabah

Dari pernyataan diatas bahwa resiko memang erat dengan pembiayaan. Adapun pembiayaan dalam BMT memiliki banyak produk, tentunya banyak nya tersebut akan dominan resiko jika terjadi nya pembiayaan bermasalah.

Heri (2013) Dalam menyalurkan dananya kepada nasabah, secara garis besar produk pembiayaan syariah terbagi dalam empat kategori yang dibedakan berdasarkan tujusn penggunaan, yaitu:

a. Pembiayaan dengan prinsip jual beli, ditujukan untuk memiliki barang, yakni menggunakan akad murabahah, salam, dan isthina'

1) Pembiayaan Murabahah

Pembiayaan murabahah adalah perjanjian jual beli antara bank dan nasabah dimana pihak bank menyediakan barang yang diperlukan nasabah 
dan kemudian menjual kepada masabah yang bersangkutan sebesar harga perolehan ditambah margin yang telah disepakati oleh kedua pihak (bank dan nasabah).

2) Pembiayaan Salam

Pembiayaan salam adalah, perjanjian jual beli barang dengan cara pemesanan dengan syarat tertentu dan pembayarannya terlebih dahulu, barang diserahkan dikemudian hari.

3) PembiayaanIsthisna

Pembiayaan isthisna' adalah perjanjian jual beli dalam bentuk pemesanan pembuatan barang denga kriteria dan persyaratan tertentu yang telah disepakati antara pemesan dan penjual.

b. Pembiayaan dengan prinsip bagi hasil, digunakan untuk usaha dan kerja sama yang ditujukan guna mendapatkan barang dan jasa sekaligus, yakni akad mudharabah dan musyarokah

1) Pembiayaan mudharabah

Pembiayaan mudharabah adalah perjanjian antara pemilik modal dan pengelola dana untuk melakukan kegiatan usaha tertentu, dengan pembagian keuntungan antara kedua pihak berdasarkan nisbah yang telah disepakati

2) PembiayaanMusyarakah

Pembiayaan musyarokah adalah perjanjian diantara pemilik modal untuk mencampurkan modal mereka pada usaha tertentu, dengan pembagian keuntungan sesuai dengan nisbah yang telah disepakati sebelumnya.

c. Pembiayaan dengan prinsip sewa, ditujukan untuk mendapatkan jasa, yakni menggunakan akad ijarah dan akad ijarah mumtahiya bit tamlik

1) Pembiayaan Ijarah

Ijarah adalah akad pemindahan hak guna atas barang dan jasa, melalui pembayaran upah sewa tanpa diikuti dengan pemindahan hakkepemilikan atas barang tersebut.

2) Pembiayaan Ijarah mumtahiya bit tamlik

yaitu akad sejenis perpaduan antarakontrak jual beli dan sewa atau lebih tepatnya akad sewa yang diakhiridengan perpindahan kepemilikan barang dari pihak yang memberikan sewakepada pihak penyewa Sifat pemindahan kepemilikan ini yang membedakandengan ijarah biasa.

d. Pembiayaan menggunakan prinsip akad pelengkap, yakni akad qard, rahn, dan kafalah

1) Pembiayaan Qard

Pembiayaan qard adalah pinjaman tanpa dikenakan biaya (hanya membayar sebesar pokok utangnya). Pinjaman seperti inilah yang sesuai syariah (tidak ada riba).

2) Pembiayaan Rahn

Pembiayaan rahn yaitu sebuah perjanjian pinjaman dengan jaminan atau dengan melakukan penahanan harta milik si peminjam sebagai jaminan.

3) Pembiayaan Kafalah 
Pembiayaan kafalah yaitu perjanjian pemberian jaminan yang diberikan oleh penanggung kepada pihak ketiga untuk memenuhi kewajiban pihak kedua atau pihak yang ditanggung.

Pembiayaan yang dijelaskan secara rinci diatas sangat memungkin sekali akan terjadi nya resiko. Meskipun profit utama BMT dari pembiayaan namun dilain sisi juga memiliki nilai resiko yang rentan tinggi atau rendah. Adapun BMT Al Fithrah ataupun lembaga keuangan bank atau non bank akan mengambil resiko yang paling kecil dan keuntungan yang lebih besar, BMT Al Fithrah mengatur resiko pembiayaan sejak nasabah melakukan pembiayaan pertama kali, contoh : mas ibrohim melakukan pembiayaan sebesar 10.000.000 dengan jaminan sepeda motor seharga 18.000.000 dengan pekerjaan mas ibrohim disini sebagai ojek online,dengan angsuran 1.000 .000 per bulan. sebelum BMT Al Fithrah memberi pembiayaan tersebut, BMT akan melakukan analisis pembiayaan terlebih dahulu, analisis pembiayaan disini bertujuan untuk meminimalisir resiko pembiayaan nasabah terhadap BMT Al Fithrah . Salah satu resiko pembiayaan di sini seperti:

1. Dari segi jaminan

Jamina sepeda motor semakin lama akan semakin turun maka

BMT Al Fithrah akan melihat terkebih dahulu berapa lama jangka pembiayaan mas ibrohim. Jika jangka pembiayaan satu tahun maka BMTakan mentaksasi jaminan $50 \%$ dari harga motor tersebut, jika harga motor tersebut setelah di kalkulasikan $50 \%$ dan manghasilkan harga di bawah pengajuan pembiayaan maka BMT tidak akan memberikan pembiayaan karena memiliki resiko yang besar

2. Dari segi pendapatan

BMT Al Fithrah akan menanyakan pendapatan mas ibrohim perhari dari ojek online tersebut, jika pendapatan mas ibrohim disini senilai 100.000 dengan perincian hanya bisa membayar 30.000 untuk membayar angsuran setiap hari, maka BMT akan mengkalkulasikan pendapatan mas ibrohim selama satu bulan, jika setelah dikalkulasikan dan hasilnya tidak sampai dengan pembayaran angsuran, maka BMT Al Fithrah tidak akan memberikan pembiayaan.

Fathur Rozi (BMT Al Fithrah) Sebelum BMT Al Fithrah akan memberikanpembiayaan kepada nasabah, BMT alfthrah akan dilihat terlebih dahulutentang kemampuan nasabah untuk membayar pembiayaan dan nilai jaminan yang dililiki oleh nasabah tersebut.

Ibnu Sofyan (2005) esensi dari manajemen resiko adalahsuatu cara, metode, atau ilmu pengetahuan yang mempelajari berbagai jenis resiko.Bagaimana resiko itu terjadi dan mengelola resiko tersebut dengan tujuan agar terhindardari kerugian, atau usaha untuk menggunakan sumber daya secara efektif untuk mencapaisasaran dan usaha seorang manajer untuk mengatasi kerugian secara rasional agar tujuanyang diinginkan dapat tercapai secara efektif dan efisien. 
Secara umum tujuan dari manajemen resiko adalah:

a. Agar perusahaan tetap hidup dan tambah maju dengan perkembangan dan berkesinambungan

b. Memberikan rasa aman baik nasabah dan LK

c. Biaya risk manajement yang efisien dan efektif

d. Agar pendapatan perusahaan stabil dan wajar, memberikan kepuasan dari pemilik dan pihak lain.

Berdasarkan tujuan yang telah dijelaskan diatas maka secara umum penerapan manajemen resiko disuatu perusahaan merupakan salah satu cara untuk tercapainya tujuan perusahaan.

\section{Menghindari Resiko Pembiayaan Di BMT Al Fithrah}

Kasmir (2013) Pembiayaan adalah pemberian fasilitas penyediaan dana untuk memenuhi kebutuhan pihak-pihak yang merupakan deficit unit. Dan Pembiayaan dalam secara luas diartikan sebagai pendanaan yang di keluarkan untuk mendukung investasi yang telah direncanakan baik dilakukan sendiri maupun dijalankan oleh orang lain.

Pembiayaan secara luas berarti financing atau pembelanjaan, yaitu pendanaan yang dikeluarkan unruk mendukung investasi yang telah direncanakan, baik dilakukan sendiri maupun dijalankan orang lain.

Berdasarkan pengertian tersebut diatas, dapat disimpulkan bahwa pembiayaan adalah pemberian fasilitas penyediaan dana untuk mendukung investasi yang telah direncanakan berdasarkan kesepakatan antara bank dengan pihak lain yang mewajibkan pihak yang dibiayai untuk mengembalikan uang atau tagihan tersebut setelah jangka waktu tertentu dengan imbalan atau bagi hasil.

Salusu (1996) Adapun Strategi merupakan sebuah seni menggunakan kecakapan dan sumber daya untuk bisa mencapai sasaran, definisi lainnya menjelaskan bahwa sekumpulan program-program dalam jangka panjang untuk mencapai tujuan/sasaran, kebijakan dan pelaksanaan kegiatan. Kesuksesan sebuah strategi sangat ditentukan oleh sasaran atau tujuan yang ingin dicapai. Berhubungan dengan pembiayaan, maka perlu juga dipahami bahwa beberapa pembiayaan yang sudah ada tanda-tanda bermasalah membutuhkan penangan secara tepat, cepat dan komprehensip atau dengan kata lain membutuhkan suatu strategi yang segera, satu diantaranya adalah pembiayaan macet. Pembiayaan bermasalah yang berpotensi macet diantaranya adalah bridge financing pembiayaan kepada perusahaan induk income tidak jelas, project financing, pembiayaan kepada unit usaha yang diteruskan kepada unit usaha lainnya dengan bentuk struktur pembiayaan yang kurang tepat.

Strategi yang digunakan didalam BMT Al Fithrah untuk menghindari resiko pembiayaan yaitu dengan cara melakukan kesepakatan atau bermusyawarah terlebih dahulu antara AO (account offiser)dengan nasabah sebelum memberikan pembiayaan, jika dalam kesepakatan tersebut belum selesai maka proses kesepakatan tersebut dilakukan ketika mensurvey nasabah, hal tersebut dilakukan supaya dari pihak BMTdan pihak nasabah disini tidak ada yang di rugikan. Strategi yang digunakan disini mencakup menganalisa dan mensurvey utang pembiayaan, perekonomian, dan karakter dari nasabah. 
1. Jumlah Utang pembiayaan

BMT Al Fithrah akan menganalisa dan mensurvey terlebih dahulu berapa jumlah pembiayaan yang akan dilakukan oleh nasabah, hal ini bertujuan supaya jumlah pembiayaan yang dilakukan nasabah tidak ada dana lebih dalam pembiayaan.

2. Perekonomian

BMT Al Fithrah sebelum memberikan pembiayaan akan melakukan penganalisaan dan pensurvean tentang perekonomian dari nasabah, hal ini bertujuan untuk mengetahui pendapatan nasabah untuk melihat kemampuan pembayaran pembiayaan dari nasabah

3. Karakter

BMT Al Fithrah akan mensurvey terlebih dahulu tentang karakter dari nasabah sebelum memberikan pembiayaan, dalam pensurveyan ini juga melibatkan masyarakat sekitar nasabah, BMTalfihtah akan menanyajan tentang karakter nasabah ke masyarakat sekitar bagaimana sifat dan prilaku dari nasabah, hal ini bertujuan untuk antisipasi agar tidak terjadi kredit macet atau nasabah tidak membayar pembiayaan ke BMT Al Fithrah .

Rachmat Firdaus dan Maya Ariyanti (2009) Untuk menimalisir sebuah resiko biasanya sebuah perusahaan akan menggunakan sebuah prinsip $5 \mathrm{C}$. Penilaian dengan prinsip 5C adalah sebagai berikut:

\section{a. Character}

Character merupakan sifat atau watak seseorang. Sifat atau watak dari orang-orang yang akan diberikan kredit benar-benar harus dapat dipercaya.

b. Capacity

Capacity adalah kemampuan nasabah untuk menjalankan usahanya guna memperoleh laba sehingga dapat mengembalikan pinjaman/pembiayaan dari laba yang dihasilkan. Penilaian ini bermanfaat untuk mengukur sejauh mana calon mudharib mampu melunasi utang-utangnya secara tepat waktu, dari hasil usaha yang diperolehnya.

c. Capital

Capital adalah jumlah dana/modal sendiri yang dimiliki oleh calon mudharib. Makin besar modal sendiri dalam perusahaan, tentu semakin tinggi kesungguhan calon mudharib menjalankan usahanya dan bank akan merasa lebih yakin memberikan pembiayaan.

d. Collateral

Collateral adalah barang yang diserahkan mudharib sebagai agunan terhadap pembiayaan yang diterimanya. Collateral harus dinilai oleh bank untuk mengetahui sejauh mana resiko kewajiban financial mudharib kepada bank. Penilain terhadap agunan ini meliputi jenis, lokasi, bukti kepemilikan, dan status hukumnya.

e. Condition

Condition adalah menilai kredit dengan menilai kondisi ekonomi, sosial, dan politik yang ada sekarang dan prediksi untuk di masa yang akan datang. Penilaian kondisi atau prospek bidang usaha yang dibiayai hendaknya benarbenar memiliki prospek yang baik, sehingga kemungkinan kredit tersebut bermasalah relatif kecil. 
OJK (Otoritas Jasa Keuangan) sampai saat ini masih menggunakan istilah resiko kredit terkait penerapan manajemen resiko bagi Bank Umum Syariah dan Unit Usaha Syariah. Adapun pengaturan dalam masalah ini dapat ditemukan dalam POJK No.65/POJK.3/2016 tentang Penerapan Manajemen resiko bagi Bank Umum Syariah dan Unit Usaha Syariah. Untuk kegiatan usaha perbankan syariah tidak terlepas dari yang namanya resiko yang dapat mengganggu dan menjadi kendala dalam kelangsungan bank. Kemudian untuk mengelola resiko tersebut bank wajib mengaplikasikan manajemen resiko secara individu dan secara konsolidasi. Karakteristik produk dan jasa perbankan syariah memerlukan fungsi identifikasi, pengukuran, pemantauan, dan pengendalian resiko yang sesuai dengan kegiatan usaha perbankan syariah. Resiko sendiri diartikan sebagai potensi kerugian akibat terjadinya suatu peristiwa tertentu dilapangan. Sehingga salah satu jenis resiko yang diatur oleh regulator dalam penerapan manajemen resiko perbankan adalah resiko kredit. Di lain sisi Resiko kredit timbul akibat kegagalan nasabah atau pihak lain dalam memenuhi kewajiban kepada pihak Bank sesuai dengan perjanjian yang disepakati. Termasuk di dalam nya pengertian resiko kredit akibat kegagalan debitur, resiko konsentrasi kredit, counterparty credit risk dan settlement risk.

Pemusatan atau terkonsentrasi nya penyediaan dana kepada 1 (satu) pihak/ perorangan atau sekelompok pihak, industri, sektor, dan/atau area geografis tertentu yang berpotensi menimbulkan kerugian cukup besar yang dapat mengancam kelangsungan usaha Bank. Kondisi ini dapat digolongkan dalam pengertian resiko konsentrasi pembiayaan yang menyebabkan munculnya resiko kredit. Jadi Counterparty credit risk merupakan penyebab munculnya resiko kredit. Bagaimanapun juga keadaan ini muncul di saat terjadinya kegagalan pihak ketiga dalam memenuhi kewajibannya dan timbul dari jenis transaksi yang memiliki karakteristik tertentu, misalnya transaksi yang dipengaruhi oleh pergerakan nilai wajar atau nilai pasar. Sedangkan settlement risk merupakan resiko yang timbul akibat kegagalan penyerahan kas dan/atau instrumen keuangan pada tanggal penyelesaian (settlement date) yang telah disepakati dari transaksi penjualan dan/atau pembelian instrumen keuangan. Djunaidi D Kamil (2019)

\section{Penerapan Prinsip Kehati-Hatian Di BMT Al Fithrah}

Siswanto (2000) Lembaga bank atau lembaga lainnya harus menerapkan dan menjalankan prinsip kehati-hatian dalam upaya mencegah dan meminimalisir akan terjadinya risiko pembiayaan bermasalah. selanjutnya dalam prinsip kehatihatian tersebut salah satunya adalah dengan melakukan analisis beberapa yang menjadi aspek-aspek pertimbangan dalam pemberian pembiayaan kepada debitur, prinsip kehati-hatian yang dimaksud adalah dengan menganalisis Character, Capital, Capacity, Collateral, condition of economy. Adapun dalam upaya mengurangi resiko pembiayaan bermasalah, bank atau BMT mewajibkan nasabah untuk menyerahkan jaminan kredit. Jaminan tersebut berperan sebagai penyelamat kredit apabila nasabah menunggak pembayaran kredit, setelah melalui proses hukum tertentu, bank dapat menjual secara lelang (mengeksekusi) harta jaminan atau menagihkan kredit tertunggak kepada penjamin. 
Menurut Remi Syahdaini (1999) bahwa apabila Undang-Undang No 7 Tahun 1992 tentang Perbankan belum secara eksplisit menentukan bahwa kegiatan operasional usaha bank dengan menggunakan bagi hasil harus juga memperhatikan pentingnya prinsip kehati-hatian (prudential principle) yang akan muncul dimana operasionalnya dijabarkan kedalam rambu-rambu kesehatan bank (prudential standards) yang secara jelas dan tegas diberlakukan bagi bank konvensional, maka dalam Undang-Undang No. 10 Tahun 1988 yang merupakan perubahan terhadap beberapa ketentuan dalam Undang-Undang No. 7 Tahun 1992 itu telah dengan tegas menentukan bahwa prinsip dan rambu-rambu tersebut harus pula diperhatikan dan dipatuhi oleh bank-bank yang melakukan kegiatannya berdasarkan Prinsip Syariah. Oleh sebab itu, hal ini juga ditegaskan dalam suratsurat keputusan kebijakan direksi Bank Indonesia yang merupakan ketentuanketentuan pelaksanaan dari Undang-Undang No. 10 Tahun 1998 tersebut.

Ada beberapa pendekatan analisa pembiayaan yang dapat diterapkan oleh pengelola bank syari'ah dalam kaitannya dengan pembiayaan yang akan dilakukan, yaitu:

a. Pendekatan jaminan, bank dalam memberikan pembiayaan selalu memperhatikankuantitas dan kualitas jaminan yang dimiliki oleh peminjam.

b. Pendekatan karakter, bank mencermati secara sungguh-sungguh terkait dengankarakter nasabah.

c. Pendekatan karakter, bank menganalisis kemampuan nasabah untuk melunasi jumlahpembiayaan yang telah diambil.

d. Pendekatan dengan studi kelayakan, bank memperhatikan kelayakan usaha yangdijalankan oleh nasabah peminjam.

e. Pendekatan dengan studi kelayakan, bank memperhatikan kelayakan usaha yangdijalankan oleh nasabah peminjam

Ada beberapa prinsip kehati-hatian di BMT Al Fithrah sebelum memberikan pembiayaan kepada nasabah, yaitu:

1. BMT Al Fithrah sebelum memberikan pembiayaan kepada nasabah akan melakukan pensurveyian terlebih dahulu ke tetangga atau di sekitar tempat bekerja nasabah, yang mencakup tentang kepribadian nasabah, dan mensurvey apakah nasabah tersebut mempunyai hutang atau tidak.

2. BMT Al Fithrah sebelum memberikan pembiayaan akan mensurvey sumber pendapatan calon nasabah tersebut.

BMT Al Fithrah dalam prinsip kehati-hatian juga menerapkan prinsip caracter, capacity, capital, corateral:

a. Character

Rohmatan (2015) Penilaian karakter dilakukan oleh BMT kepada nasabah untuk mengetahui itikad dari nasabah tersebut, baik perilaku sehariharinya, wataknya dan sifat-sifat pribadi yang dimiliki nasabah tersebut. Hal ini bertujuan untuk mengetahui apakah karakter yang dimiliki nasabah tersebut memang benar-benar baik atau kurang baik. Walaupun nasabah tersebut diyakini mampu secara finansial untuk memenuhi kewajiban, namun jika nasabah tersebut memiliki itikad yang kurang baik maka BMT akan mempertimbangkan untuk pemberian pembiayaan atau bisa jadi bank tidak akan merealisasi pembiayaan yang diajukan. 
b. Capacity

Irfan Fahmi (2014) Penilaian kemampuan nasabah untuk menjalankan usaha guna memperoleh laba yang nanti akan dapat digunakan untuk mengembalikan pembiayaan yang diberikan lembaga keuangan kepada nasabah.

c. Capital

Capital digunakan untuk melihat seberapa besar penggunaan modal dalam kegiatan usahanya, apakah modal yang selama ini digunakan sesuai dengan laporan keuangan yang diberikan calon nasabah kepada BMT atau justru antara modal yang ada dengan penggunaan modal untuk pengelolaan usaha tidak sesuai atau terdapat kejanggalan.

d. Collateral

Thamrin Abdullah (2014) Collateral atau yang sering disebut dengan jaminan adalah barang atau sesuatu yang berharga dan memiliki nilai untuk dijadikan sebagai penjamin bagi calon nasabah untuk mengajukan pembiayaan kepada bank syariah.

\section{Penutup}

BMT Al Fithrah maupun lembaga keuangan bank atau non bank akan mengambil resiko yang paling kecil dan keuntungan yang lebih besar, BMT Al Fithrah mengatur resiko pembiayaan sejak nasabah melakukan pembiayaan pertama kali. Strategi yang digunakan didalam BMT Al Fithrah untuk menghindari resiko pembiayaan yaitu dengan cara melakukan kesepakatan atau bermusyawarah terlebih dahulu antara AO (account offiser) dengan nasabah sebelum memberikan pembiayaan

Ada beberapa prinsip kehati-hatian di BMT Al Fithrah sebelum memberikan pembiayaan kepada nasabah, yaitu: karekteristik nasabah dan sumber pendapatan nasabah.

\section{Referensi}

Dewy Anita, Urgensi Akad Dalam Transaksi Bisnis Islam, Jurnal Madani Syari'ah Vol. 2, 15-30

Fathur Rozi, Penanggung Jawab pembiayaan BMT Al Fithrah .

Hery,(2018) Akutansi Syariah, PT. Grasindo, Jakarta.

Iban Sofyan, (2005) Manajemen Risiko, Graha Ilmu, Yogyakarta.

Irham Fahmi, (2014) Manajemen Perkreditan, Alfabetha, Bandung.

Irdlon Sahil, Potensi Baitul Maal Wat Tamwil (Bmt) Dalam Meningkatkan Pertumbuhan Ekonomi Di Indonesia, Jurnal Al-Insyiroh: Jurnal Studi Keislaman, Vol. 5, No. 2, 30-45

Rachmat Firdaus dan Maya Ariyanti, (2009) Manajemen Perkreditan Bank umum. Alfabeta, Bandung.

Rodoni, Ahmad, Abdul Hamid, (2008) Lembaga Keuangan Syariah, Publisher, Jakarta. 
Rohmatan, Analisis Implementasi Prinsip 5C dalam Upaya Pencegahan Pembiayaan Mudharabah Bermasalah di KSPPS BMT UMMAT SEJAHTERA (BUS) Cabang Cepu, 2015.

Sutojo Siswanto, (2000). Strategi Manajemen Kredit Bank Umum. Damar Mulia Pustaka, Jakarta.

Salusu, J. (1996). Pengambilan Keputusan Stratejik Untuk Organisasi Publik dan Organisasi Non Profit, PT Grasindo, Jakarta.

Siradjuddin. Ketertarikan Aspek pengelolaan, Akad Sebagai Bingkai Transaksi Bisnis Syariah, Jurnal Jurisprudence, Vol. 7 No. 2, 1-14

Thamrin Abdullah dan Francis Tantri, (2014) Bank dan Lembaga Keuangan, PT Raja Grafindo Persada, Jakarta.

https://analisadaily.com/berita/arsip/2019/11/2/817132/risiko,pembiayaan perbankan-syariah/ diakses tanggal 1 April 2021, Jam 1.00

Karim Adiwarman A.(2006) “Bank Islam Analisis Fiqih dan Keuangan”, PT Raja Grafindo Persada, Jakarta. 